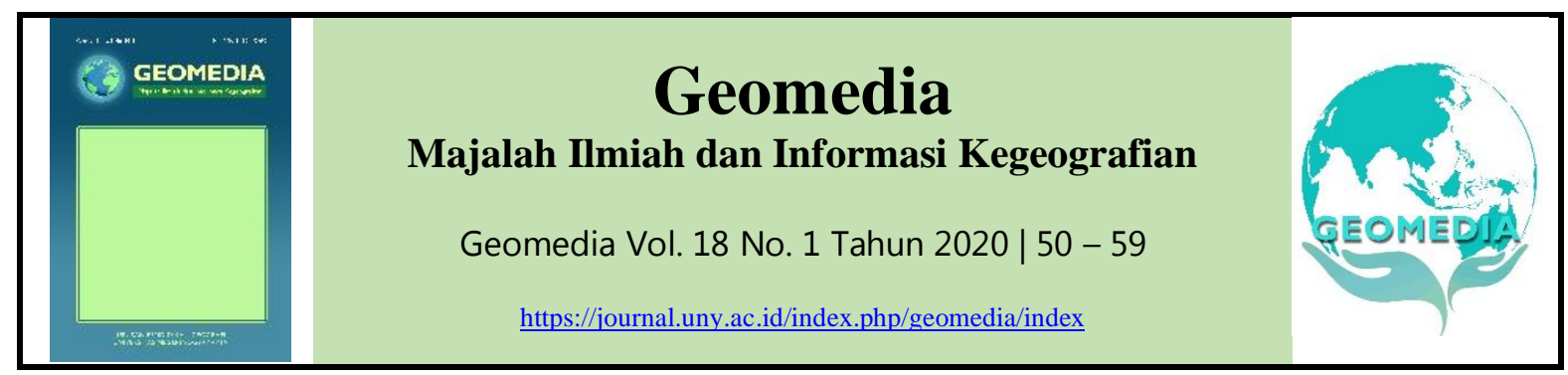

\title{
Pengukuran dasar telaga menggunakan alat perum gema untuk menghasilkan peta batimetri di Telaga Winong Yogyakarta
}

\author{
Erik Febriarta $^{\text {a, }{ }^{*} \text {, Septian Vienastra }}{ }^{\text {b, }}{ }^{2}$, Agus Suyanto ${ }^{a, 3}$, Ajeng Larasati ${ }^{c, 4}$ \\ a Fakultas Teknologi Sumber Daya Alam, Institut Teknologi Yogyakarta, Yogyakarta \\ b Jurusan Teknik Geologi, Fakultas Teknologi Minieral, Institut Sains dan Teknologi AKPRIND, Yogyakarta \\ c Palawakarya, Yogyakarta \\ ${ }^{1}$ e.febriarta@gmail.com*; ${ }^{2}$ vienastra@akprind.ac.id; ${ }^{3}$ sttlylh@gmail.com; ${ }^{4}$ ajlarasati@gmail.com \\ *korespondensi penulis
}

\begin{tabular}{ll}
\hline \multicolumn{2}{l}{ Informasi artikel } \\
\hline Sejarah artikel & \\
Diterima & $: 08$ April 2020 \\
Revisi & $: 02$ Mei 2020 \\
Dipublikasikan & $: 31$ Mei 2020 \\
\hline
\end{tabular}

\section{A B S T R A K}

Telaga Winong merupakan salah satu telaga yang tidak kering pada musim kemarau. Telaga ini berada di Desa Kepek, Kecamatan Saptosari, Kabupaten Gunungkidul, Provinsi Daerah

\section{Kata kunci:}

Telaga

Perum Gema

Batimetri

Sistem informasi geografis (SIG)

\section{Keywords: \\ Lake \\ Echosounder \\ Bathymetry \\ Geographic Information System \\ (GIS)} Istimewa Yogyakarta. Tujuan dari penelitian ini adalah mengetahui nilai kedalaman dasar telaga atau topografi dasar telaga untuk menghasilkan peta batimetri. Untuk mencapai tujuan tersebut maka dilakukan survei pengukuran kedalaman dasar telaga dengan instrumen perum gema (echosunder). Prinsip dari perum gema (echosunder) adalah perhitungan perambatan gelombang didalam air untuk mengetahui waktu dan jarak perambatan, sehingga mengasilkan nilai kedalaman (m). Data nilai kedalaman telaga dilakukan analisis dengan pendekatan interpolasi dengan membandingkan nilai Root Mean Squared Error (RMSE) terkecil dari metode Inverse Distance Weighting (IDW), kriging dan natural neighbour dengan cross validation pembobotan power $0,5,1$, 2, dan 3 pada setiap metode. Hasil penelitian menunjukkan bahwa nilai RMSE terendah dari interpolasi dengan cross validation ditunjukkan pada hasil interpolasi kriging dengan faktor pembobot/power 3, yaitu 0,005. Berdasarkan hasil tersebut diketahui kedalaman telaga antara $-0,2$ hingga $-1,8 \mathrm{~m}$, dengan lokasi terdalam di tengah telaga.

A B S T R A C T
Lake Winong is one lake that is not dried on dry season. This lake
is located in the Village Kepek, District Saptosari, Gunung Kidul
Regency, Special Region Province Yogyakarta. This study was
designed to determine the depth or bottom topography of Lake
Winong to produce bathymetry maps. Firstly, a survey was
conducted to measure the depth with an echosounder
instrument. Principally, an echosounder records the time interval
required by the emitted sound wave to propagate to the bottom
and return, from which the distance or depth (m) can be
computed. Secondly, the depth data were interpolated by initially 
cross-validating the smallest Root Mean Squared Errors (RMSE) of the Inverse Distance Weighting (IDW), kriging, and natural neighbor methods. Each was run with the power values (weight factors) of $0.5,1,2$, and 3 . The results showed that kriging interpolation with a power value of 3 yielded the smallest RMSE, namely 0.005 , and the lake observed was -0.2 to $-1.8 \mathrm{~m}$ deep, with the deepest location found in the middle of the lake.

(C) 2020 (Erik Febriarta, dkk). All Right Reserved

\section{Pendahuluan}

Secara pembentukan alami, telaga merupakan bentukan depresi yang terisi oleh air (Singhal \& Gupta, 2010). Telaga atau danau merupakan area perairan atau genangan yang terbentuk secara alami di tengah daratan, biasanya dicirikan oleh adanya batas yang tegas antara tubuh air dan daratan, serta genangan yang relatif dalam (Badan Standardisasi Nasional, 2014). Kenampakan telaga lebih banyak ditemukan di daerah dengan litologi batuan batugamping atau kapur. Telaga-telaga yang terbentuk di kawasan karst merupakan bentukan dari pelarutan dari batugamping yang dilarutkan oleh proses air permukaan yang meresap menuju bawah tanah (White, 1988).

White (1988) menyebutkan bahwa salah satu faktor yang dominan pemicu atau intensifnya terjadinya pelarutan sehingga membentuk cekungan hingga kedalam permukaan adalah intensitas curah hujan Sehingga banyak ditemukan telaga-telaga di kawasan karst yang merupakan bentukan depresi atau cekungan-cekungan dipermukaan tanah karena proses pelarutan tersebut. Di kawasan karst telaga-telaga banyak tergenang air pada saat musim penghujan dan kering pada saat musim kemarau. Telaga merupakan salah satu dari sumber daya air dengan fungsi menyimpan air untuk kebutuhan hidup makhluk hidup dan lingkungan disekitarnya.

Menurut Widyastuti dan Haryono (2016) menyebutkan bahwa peran telaga di daerah dengan kondisi rawan kekeringan merupakan salah satu solusi dalam pemenuhan air bersih selain pemanfaatan cadangan air tanah yang terbatas bagi masyarakat dan lingkungan pada saat musim kemarau (kering). Pemenuhan kebutuhan air bersih sehari-hari dikawasan karst diperoleh dari telaga-telaga yang tidak surut atau kering pada musim kemarau (Bappeda Kabupaten Gunungkidul, 2007).

Telaga perlu dikelola dengan baik dan dipertahankan fungsinya karena berperan sangat penting dalam pemenuhan kebutuhan air disuatu wilayah dengan kondisi kekeringan. Pemantauan, pemelihraan dan evaluasi untuk menjaga keberlangsungan keberadaan air di telaga atau danau adalah pemantauan dan pengukuran curah hujan, pengukuran laju evaporasi, pengukuran berkala kedalaman dasar dengan pembuatan peta batimetri, sebaran sedimen, pengukuran debit air masuk dan debit keluar telaga atau danau, pengukuran tinggi permukaan air (water level) dan pemantauan kualitas air (Bappeda Kabupaten Gunungkidul, 2007; Widyastuti \& Haryono, 2016: PPPSDAK PU, 2017b).

Informasi dasar dalam pengelolaan telaga/danau/embung adalah tersedianya data kapsitas tampungan yang diperoh dari data kedalaman dasar perairan atau dari data batimetri telaga (PPPSDAK PU, 2017a). Peta batimetri telaga/embung/waduk dapat memberikan informasi tampungan atau kapasitas dari volume air yang tertampung yang dapat digunakan sebagai dasar pengelolaan sumberdaya air dengan pembaharuan data dinamika air untuk merepresentasrikan kondisi telaga (McComas, 2003; PPPSDAK PU, 2017a; Febriarta, 2016).

Telaga Winong merupakan salah satu telaga yang tidak kering pada musim kemarau (Bappeda Kabupaten Gunungkidul, 2007). Secara administrasi Telaga Winong berada di 
Desa Kepek, Kecamatan Saptosari, Kabupaten Gunungkidul, Provinsi Daerah Istimewa Yogyakarta (Gambar 1). Telaga Winong berada di atas formasi Wonosari. Secara genesis terbentuknya selaras di atas Formasi Sambipitu terdapat Formasi Oyo - Wonosari. Formasi ini terutama terdiri dari batugamping dan napal (Surono, Toha dan Sudarno, 1992). Penyebarannya meluas hampir setengah bagian dari Pegunungan Selatan memanjang ke timur, membelok ke arah utara di sebelah Perbukitan Panggung hingga mencapai bagian barat dari daerah depresi Wonogiri - Baturetno. Berdasarkan kondisi stratigrafi batuan di telaga winong berupa lingkungan pengendapan dari perselingan batugamping dan napal pada bagian dasar telaga (Surono, Toha dan Sudarno, 1992).

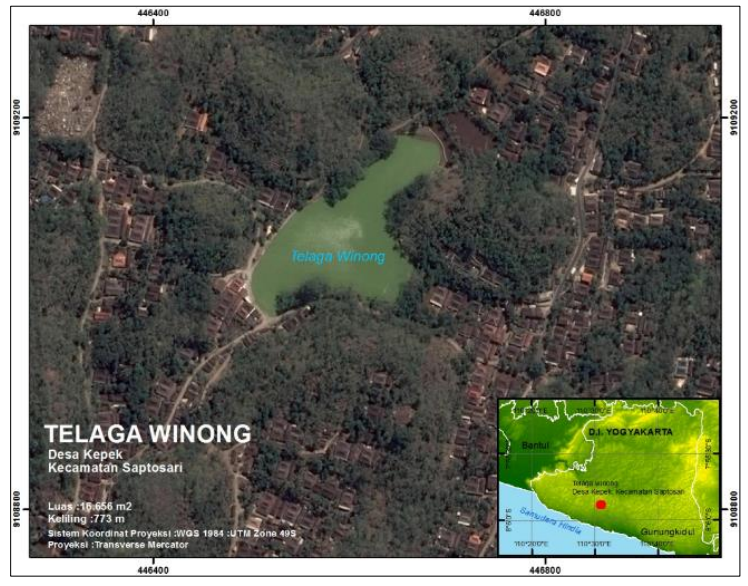

Gambar 1. Telaga Winong di Desa Kepek,

Saptosari, Gunungkidul (Febriarta, 2016)

Telaga Winong mendapat imbuhan air dari aliran permukaan di sekitar telaga, tetapi tidak terdapat aliran permukaan berupa sungai perinial atau tetap mengalir sepanjang musim. Menurut Asdak (2010) daerah yang tidak memiliki pola aliran sungai pemukaan sebagai sumber/imbuhan, memiliki keterbatasan dan kerentanan sumberdaya air. Berdasarkan latar belakang tersebut, maka tujuan dari penelitian ini adalah menentukan kedalaman pola dasar Telaga Winong atau peta batimetri Telaga Winong.

\section{Metode}

Penelitian ini terbagi menjadi 3 tahapan, yaitu persiapan, survei lapangan dan analisis data. Tahapan persiapan berupa pembuatan jalur survei untuk pemetaan kedalaman telaga. Tahapan survei lapangan berupa pencatatan data koordinat dan kedalaman telaga. Tahapan analisis data berupa interpolasi data kedalaman telaga untuk pembuatan kontur dan peta batimetri. Tahapan penelitian disajikan dalam bentuk diagram pada Gambar 2.

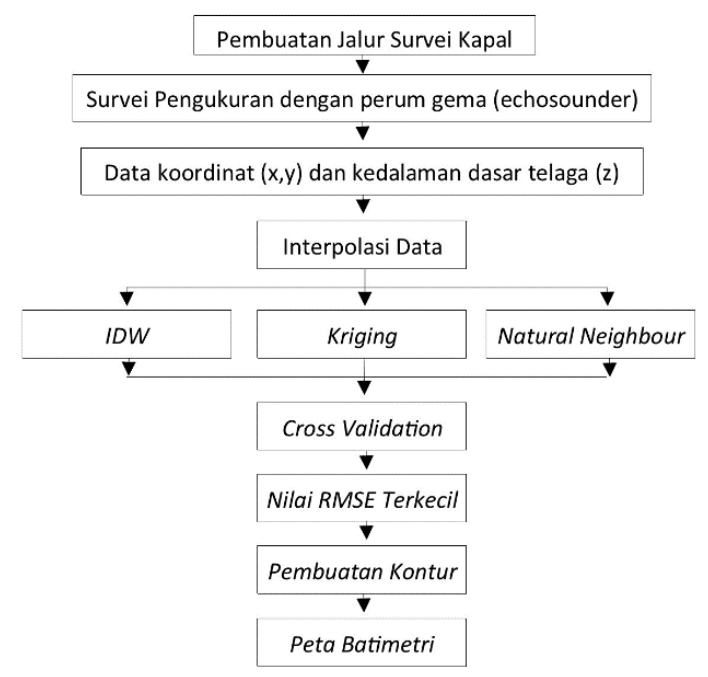

Gambar 2. Diagram alir penelitian

Lokasi pengukuran berada di Telaga Winong yang berada di Desa Kepek, Kecamatan Saptosari, Kabupaten Gunungkidul. Pengukuran dasar telaga dilakukan di seluruh bagian tubuh air telaga. Pengukuran dilakukan pada musim hujan untuk mendapatkan kondisi dinamis dimana posisi air tertinggi. Pengukuran menggunakan kapal dengan alat pengukur kedalaman berupa instrumen perum gema (echosunder) yang dilengkapi dengan koordinat lokasi atau Global Positioning System (GPS).

Analisis hasil pengukuran menggunakan pendekatan interpolasi dengan membandingkan hasil analisis nilai Root Mean Squared Error (RMSE) terkecil dari Inverse Distance Weighting (IDW), kriging dan natural neighbour (Gambar 2). Menurut Wackernagel (2003) menyebutkan bahwa untuk mendapatkan hasil tingkat kepercayaan yang tinggi dan evaluasi data maka perlu 
dibandingkan dengan faktor pembobot (cross validation). Nilai pembobotan yang dilakukan pada kajian penelitian ini adalah dengan pemberian nilai power $0,5,1,2$, dan 3 . Penentuan nilai power tersebut bernilai positif untuk memberikan perbedaan hasil dari setiap interpolasi (Wackernagel, 2003).

Nilai RMSE diperlukan sebagai evaluasi nilai hasil pengukuran dan perbandingan model perhitungan yang dipakai untuk analisis. Persamaan yang digunakan untuk menghitung RMSE sebagai berikut (Isaaks \& Srivastava, 1989; Mitas L., \& Mitasova H., 1999):

$$
\begin{aligned}
& \boldsymbol{R M S E}=\left(\frac{\sum(\boldsymbol{y i}-\breve{y} \boldsymbol{i})^{1 / 2}}{n}\right) \ldots \ldots . . . \\
& \text { dimana: } \\
& \text { y : nilai hasil observasi } \\
& \breve{y}: \text { nilai hasil prediksi } \\
& \mathrm{i}: \text { urutan data } \\
& \mathrm{n} \quad \text { : jumlah data }
\end{aligned}
$$

Nilai yang terkecil didefinisikan sebagai dengan analisis interpolasi yang represenatif dengan kondisi alam dengan kesalahan data terkecil Semakin kecil nilai RMSE, maka semain mendekati nilai yang diprediksi dan observasi. Hasil pengukuran disajikan secara keruangan (spasial) dengan bantuan perangkat lunak Sistem Informasi Geografi (SIG).

\section{Pengukuran Dasar Telaga Dengan Perum Gema (Echosunder)}

Pendekatan yang digunakan untuk mengatahui dasar kedalaman telaga untuk menbuat kontur dasar telaga menggunakan instrumen perum gema (echosounder) singel beam. Instrumen perum gema (echosounder) dengan prinsip perambatan gelombang akustik dalam air untuk menghasilkan atau menentukan kedalaman atau jarak tempuh antara alat pemancar (tansduser) hingga sampai ke dasar peraiaran. Faktor yang mempengaruhi instrumen akustik mendapatkan nilai jarak tempuh antara lain adalah waktu tempuh dan waktu rambat gelombang (Yozantika \& Heliani, 2015). Rentang frekuensi instrumen singe/ beam dengan frekuensi tinggi berkisar $100-750 \mathrm{kHz}$ dan frekuensi rendah 10-50 kHz (Garmin, 2015; Talif, 2017). Persamaan untuk menghitung interval waktu tempuh gelombang akustik menjadi nilai kedalaman, sebagai berikut :

$$
D=1 / 2(v . \Delta t)
$$

dimana :

$$
\begin{aligned}
& \mathrm{D} \quad \text { : kedalaman }(\mathrm{m}) \\
& \mathrm{v} \text { : cepat rambat gelombang akuistik }
\end{aligned}
$$
$(\mathrm{m} / \mathrm{s})$

$\Delta \mathrm{t} \quad$ : interval waktu antara gelombang yang dipancarkan dan diterima (s).

Pengukuran dasar telaga untuk menentukan nilai kedalaman dasar telaga dan membuat peta batimetri telaga mengacu Standar Nasional Indonesia (SNI) nomor 8283: 2016 , tentang metode pengukuran kedalaman menggunakan alat perum gema untuk menghasilkan peta batimetri (Badan Standardisasi Nasional, 2016). Data yang diperoleh dari pengkuran antara lain adalah lokasi/koordinat $(x, y)$ dan nilai kedalaman $(z)$ (Gambar 3).

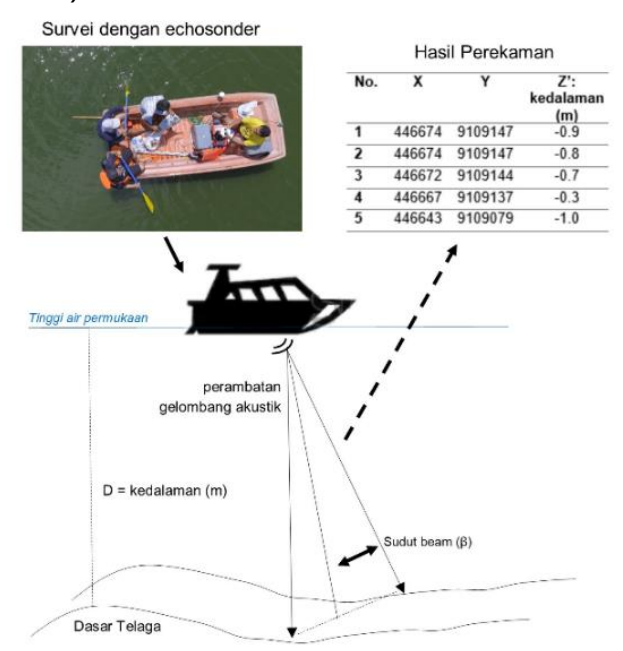

Gambar 3. Prinsip pengukuran dengan perum gema (echosounder) singel beam

(Febriarta, 2016)

\section{Analisis Interpolasi Inverse Distance Weighting (IDW) kontur kedalaman}

Interpolasi dengan menggunakan Inverse Distance Weighting (IDW) menggunakan pendekatan nilai yang saling berdekatan akan membentuk nilai yang serupa dibandingkan dengan nilai yang saling berjauhan. Metode dari 
Inverse Distance Weighting (IDW), data yang dihasilkan dipengaruhi oleh inverse jarak yang diperoleh dari persamaan sebagai berikut (Isaaks \& Srivastava, 1989; Mitas L., \& Mitasova H., 1999):

$$
W i=\frac{\frac{1}{d i p}}{\sum_{t=1}^{n} \frac{1}{d i p}}
$$

Sehingga untuk mengetahui nilai titik yang ditaksir digunakan persamaan sebagai berikut :

$$
\begin{aligned}
& \boldsymbol{Z 0}=\sum_{i=1}^{n} \boldsymbol{W i} . \boldsymbol{Z i} \\
& \text { dimana, }
\end{aligned}
$$$$
\text { Z0 : nilai titik yang ditaksir }
$$$$
\text { Wi : Faktor bobot dari titik -i }
$$$$
\mathrm{Zi} \quad \text { : Nilai dari titik penaksir -i }
$$$$
\text { di : Jarak antara titik i dengan titik }
$$$$
\text { yang ditaksir }
$$$$
\mathrm{p} \text { : Faktor eksponen (power) 0,5, 1,2, } 3 .
$$

\section{Analisis Interpolasi Natural Neighbour kontur kedalaman}

Interpolasi natural neighbour merupakan metode dengan sifat lokal, dimana sampel data yang digunakan berdekatan atau berada disekitar hasil yang diperoleh sebagai nilai masukan proses interpolasi. Metode interpolasi didasarkan pada pendekatan dengan poligon thiessen. Metode natural neighbour mempunyai kemiripan dengan metode Inverse Distance Weighting (IDW), yaitu nilai pembobotan (weight) dengan nilai yang berbeda (faktor eksponen/power) (Mitas \& Mitasova, 1999).

Persamaan untuk estimasi nilai Z (nilai yang ditaksir) dihitung dengan menggunakan persamaan (4). Nilai faktor pembobot untuk metode natural neighbour dengan faktor pembobot (weight) menggunkana persaman sebagai berikut (Merwade, Joff dan Maidment, 2006):

$$
\begin{array}{ll}
\boldsymbol{w i}=\frac{(p \boldsymbol{i}-\boldsymbol{q} \boldsymbol{i})}{p \boldsymbol{i}} \\
\text { dimana, } \\
\text { Wi } \quad \text { : Faktor bobot dari titik }-\mathrm{i} \\
\text { qi } \quad \text { : area polygon dari titik qi }
\end{array}
$$

$$
\text { pi } \quad \text { : area polygon dari titik pi }
$$

\section{Analisis Interpolasi Kriging kontur kedalaman}

Interpolasi kriging digunakan pada saat rata-rata jumlah data yang digunakan (populasi) diketahui. Metode kriging merupakan pendekatan dengan estimasi yang terregional menggukan pendekatan data (populasi data) dianggap sebagai realistis dari variabel acak dan dari keseluruhan data (populasi data) dinamis tersebut membentuk fungsi acak dengan model struktural variogram. Nilai untuk menentukan nilai Z (nilai yang ditaksir) digunkan persamaan sebagai berikut (Merwade et al., 2006):

$$
Z(s)-m(s)=\sum_{i=1}^{n} \lambda i[Z(s i)-m(s i)]
$$

dimana :

$\mathrm{s}, \mathrm{si} \quad$ : lokasi estimasi dan salah satu lokasi dari data yang berdekatan (i)

$\mathrm{m}(\mathrm{s}) \quad$ : nilai ekspektasi dari Z(s)

$\mathrm{m}(\mathrm{si}) \quad$ : nilai ekspektasi dari Z(si)

$\lambda$ : faktor bobot/faktor eksponen (power) $0,5,1,2,3$.

n : banyaknya data.

\section{Hasil dan Pembahasan}

Pengukuran dasar telaga atau topografi dasar telaga dilakukan dengan menggunakan kapal dengan pola lintasan melintang melintasi bagian tubuh air telaga. Berdasarkan hasil pengukuran dengan echosunder diketahui nilai kedalaman dasar telaga -0,2 hingga $-1,8 \mathrm{~m}$. Hasil pengukuran kedalaman $(m)$ telaga dan lintasan kapal disajikan pada Gambar 4. 


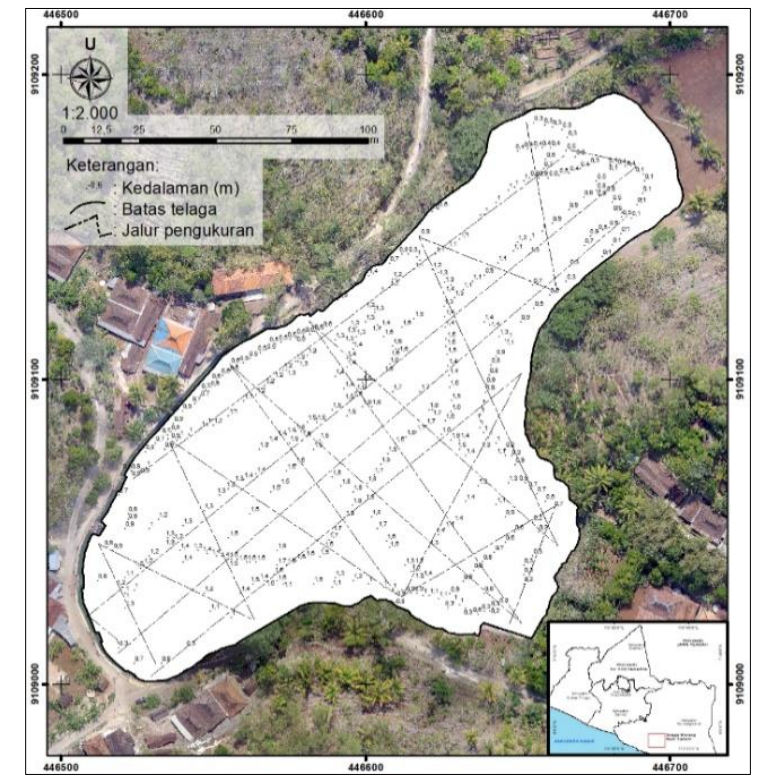

Gambar 4. Jalur survei pengukuran dan titik kedalaman Telaga Winong

\section{Interpolasi Inverse Distance Weighting (IDW)}

Hasil dari perhitungan penakisran dengan interpolasi Inverse Distance Weighting (IDW) menggunakan parameter 4 (empat) faktor pembobot / power yaitu 0,5, 1, 2, dan 3 dapat dilihat pada Tabel 1 dan Gambar 5. Nilai dari statistik interpolasi IDW mencakup nilai maksimal, minimal, rata-rata, satandar deviasi dan nilai RMSE dapat dilihat pada Tabel 1. Berdasarkan hasil perhitungan menunjukkan nilai yang semakin besar terhadap nilai pembobot/power yang besar terhadap nilai masksimal. Hal tersebut dipengaruhi oleh luasan dari populasi data pengukuran (survei)
(Gambar 5). Berdasarkan hal tersebut nilai statistik menunjukkan nilai power yang lebih besar, maka luas daerah yang diinterpolasi tersebut lebih kecil, sehingga menghasilkan hasil yang perataan (bernilai sama) yang relatif besar.

Hasil dari perhitungan prediksi nilai error / RMSE yang lebih besar (sebesar 0,023) dari nilai power yang kecil (nilai power 1), hal tersebut dipengaruhi oleh sebaran data yang diinterpolasi lebih sedikit. Sebaliknya jika nilai power yang digunkan besar (nilai power 3), diperoleh nilai RMSE paling kecil yaitu 0,006. Berdasarkan nilai tersebut pemodelan interpolasi nilai power 3 menunjukkan data yang paling representatif dan paling sesuai.

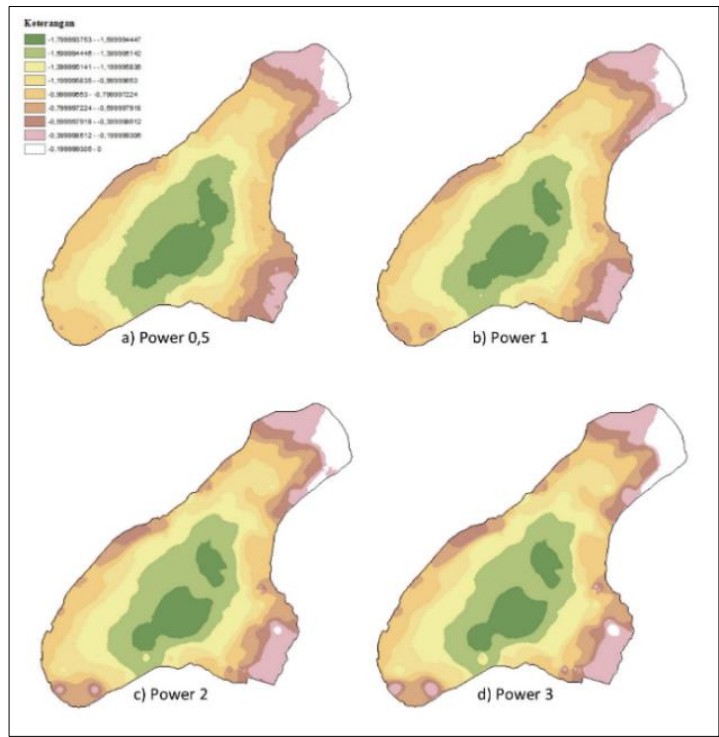

Gambar 5. Penaksiran dengan interpolasi IDW

Tabel 1. Statistik penaksiran dengan interpolasi Inverse Distance Weighting (IDW)

\begin{tabular}{llllll}
\hline Power & Max & Min & Rata-Rata & Std Dev & RMSE \\
\hline $\mathbf{0 , 5}$ & $-0,02$ & $-7,785$ & $-0,582$ & 0,429 & 0,022 \\
\hline $\mathbf{1}$ & 0 & $-1,793$ & $-0,318$ & 0,528 & 0,023 \\
\hline $\mathbf{2}$ & 0 & $-1,799$ & $-0,314$ & 0,530 & 0,021 \\
\hline $\mathbf{3}$ & 0 & $-1,799$ & $-0,312$ & 0,532 & 0,006 \\
\hline
\end{tabular}

\section{Interpolasi Natural Neighbour}

Interpolasi data kedalaman dasar telaga dengan metode natural neighbour menunjukkan sifat lokal, dimana data yang dihitung/ditaksir (data prediksi) berdasarkan kelompok data atau populasi yang saling berdekatan, sehingga data kedalaman yang diinterpolasi akan menunjukkan hasil yang serupa dengan data hasil pengukuran (data observasi/survei). Hasil statistik perhitungan interpolasi dengan natural neighbour 
menunjukkan nilai standar deviasi terkecil pada perhitungan power 0,5 yaitu 0,403 (Tabel 2).

Nilai standar deviasi terkecil tersebut menunjukkan bahwa dengan power 0,5 perhitungan interpolasi menghasilkan simpangan yang paling kecil. Tetapi berdasarkan perbandingan nilai tolak ukur, nilai rata-rata menunjukkan nilai standar deviasi lebih besar dari nilai rata-rata, yang dapat diartikan dengan nilai rerata yang buruk untuk populasi data. Hal tersebut dipengaruhi oleh tipe sebaran data yang lokal atau membentuk kelompok-kelompok, sehingga data kedalaman yang diinterpolasi akan menujukkan dengan data sampel yang digunakan.

Nilai rata-rata maksimum kedalaman diperoleh nilai -0,019 dimana nilai tersebut lebih lebih besar dari nilai yang dihasilkan dengan metode interpolasi IDW. Hasil yang diperoleh dari interpolasi ini menujukkan hasil kemiringan kontur yang relatif lebih landai dibandingkan dengan metode interpolasi IDW. Hal tersebut dipengaruhi oleh metode penaksiran dengan pendekatan sistem polygon thiessen. Pendekatan polygon thieseen didasarkan nilai interpolasi titik berdasarkan luasan area yang mengakibatkan berpengaruh terhadap titik interpolasi, seperti yang ditunjjukan pada Gambar 6.

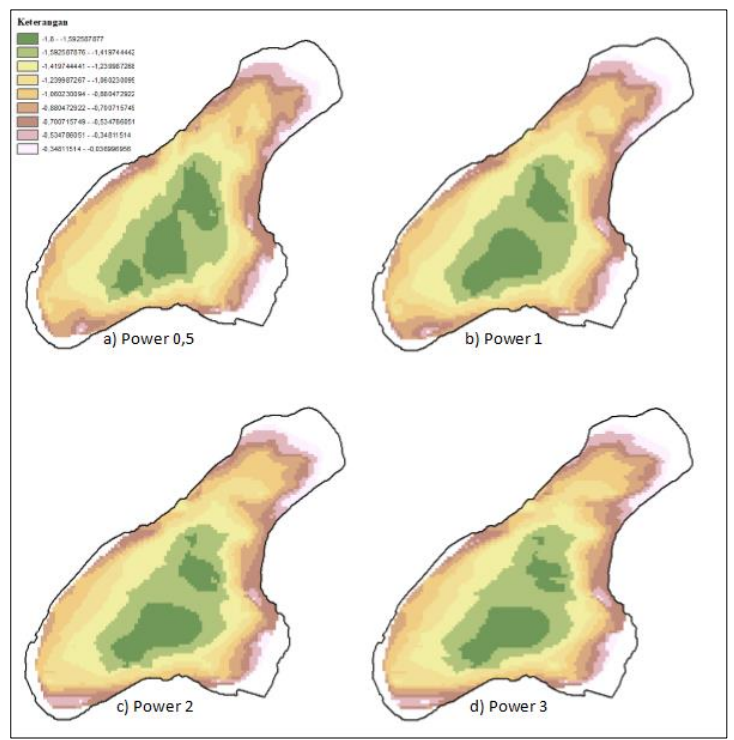

Gambar 6. Penaksiran dengan interpolasi natural neightbour

Tabel 2. Statistik penaksiran dengan interpolasi natural neighbour

\begin{tabular}{llllll}
\hline Power & Max & Min & Rata-Rata & Std Dev & RMSE \\
\hline $\mathbf{0 , 5}$ & $-0,038$ & $-1,800$ & $-1,075$ & 0,403 & 0,022 \\
\hline $\mathbf{1}$ & $-0,036$ & $-1,800$ & $-6,069$ & 0,407 & 0,021 \\
\hline $\mathbf{2}$ & 0 & $-1,799$ & $-0,314$ & 0,530 & 0,018 \\
\hline $\mathbf{3}$ & 0 & $-1,799$ & $-0,312$ & 0,532 & 0,008 \\
\hline
\end{tabular}

\section{Interpolasi Kriging}

Hasil metode interpolasi kriging yang digunakan untuk menghitung nilai kedalaman dasar telaga adalah dengan menggunkanan pendekatan simpel kriging, dimana hasilnya mempertimbangkan suatu titik yang tidak tersampel berdsarakan titik-titik yang berada disekitarnya dengan mempertimbangkan luasan atau korelasi spasial. Sehingga menghasilkan perhitungan yang memiliki sebaran data rata. Hasil interpolasi menunjukkan perbandingan nilai baku mengasilkan nilai standar deviasi lebih besar dibandingkan oleh nilai rata-rata. Secara umum ketiga metode menunjukkan hasil yang serupa.
Nilai tersebut menunjukkan bahwa data yang digunkan memiliki rerata tidak baik atau sebaran populasinya buruk. Nilai error/RMSE terrendah diperoleh dari pembobotan/power 3, yaitu dengan nilai 0,005 (Tabel 3). Nilai tersebut juga menunjukkan nilai terkecil dari seluruh perhitungan ketiga interpolasi. Sehingga dapat disimpulkan hasil terbaik adalah interpolasi kriging dengan pembobotan / power 3 . Hasil dari interpolasi menunjukkan distribusi data yang relatif halus atau menghasilkan titik yang rata, atau rapat dibanding kedua metode lain (Gambar 7). 
Tabel 3. Statistik penaksiran dengan interpolasi kriging.

\begin{tabular}{llllll}
\hline Power & Max & Min & Rata-Rata & Std Dev & RMSE \\
\hline $\mathbf{0 , 5}$ & $-0,056$ & $-1,800$ & $-0,853$ & 0,415 & 0,022 \\
\hline $\mathbf{1}$ & 0,201 & $-1,805$ & $-0,758$ & 0,506 & 0,021 \\
\hline $\mathbf{2}$ & 2,369 & $-2,618$ & $-0,532$ & 0,779 & 0,019 \\
\hline $\mathbf{3}$ & 0,201 & $-1,805$ & $-0,758$ & 0,606 & 0,005 \\
\hline
\end{tabular}

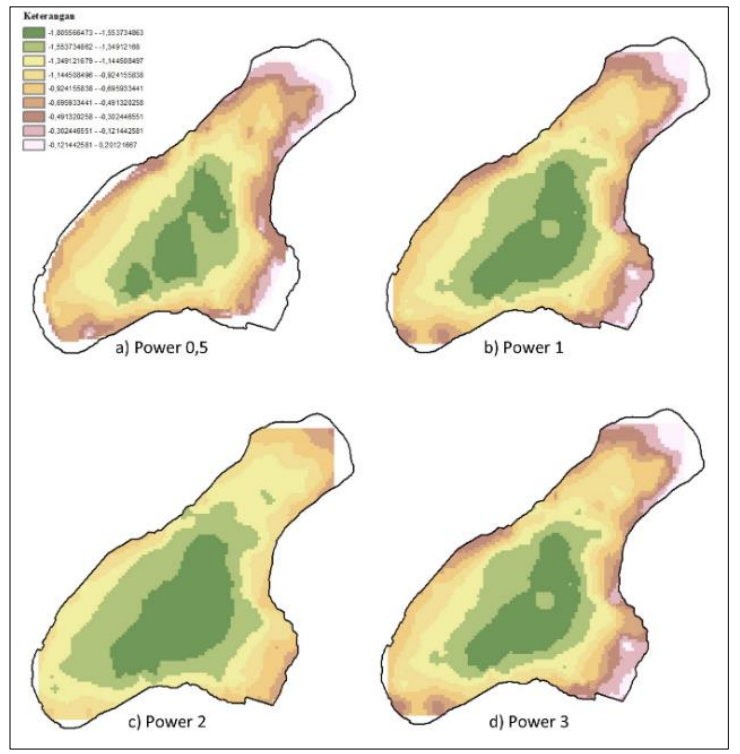

Gambar 7. Penaksiran dengan interpolasi kriging

\section{Peta Batimetri Telaga Winong}

Berdasarkan nilai RMSE dari hasil cross validation dari ketiga interpolasi dengan menggunakan metode IDW, natural neightbour, dan kriging, diketahui nilai terkecil ditunjukan dari hasil interpolasi kriging dengan pembobot / power 3, yaitu 0,005 (Tabel 3). Berdasarkan nilai tersebut diketahui bahwa hasil metode tersebut menunjukkan nilai kesalahan yang paling kecil atau menunjukkan hasil yang mendekati dari hasil pengukuran (observasi) dan hasil prediksi dari pengukuran dasar telaga. Dari hasil tersebut diolah menjadi data kontur untuk menghasilkan peta batimetri Telaga winong. Peta batimetri Telaga Winong disajikan pada (Gambar 8).

Berdasarkan hasil interpolasi diketahui lokasi terdalam berada di bagian tengah dari telaga, dengan kedalaman -1,8 m dan menunjukkan data yang dangkal disekitar pinggir telaga (Gambar 9).

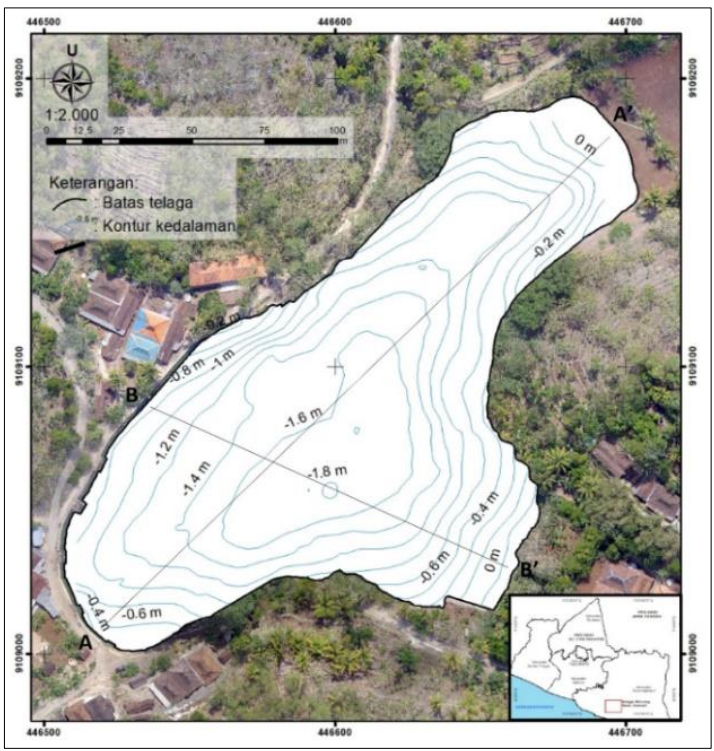

Gambar 8. Peta batimetri Telaga Winong

Kemiringan dasar telaga di bagian selatan memiliki sudut $25^{\circ}$, sedangkan pada bagian utara lebih terjal dengan sudut $33^{\circ}$. Profil penampang dasar telaga arah barat daya ke timur laut (A-A') disajikan pada Gambar 9, dan penampang dasar telaga arah barat laut ke tenggara (B-B') daisajikan pada Gambar 10. Perbedaan kemiringan dasar telaga bagian utara lebih terjal dimungkinkan karena, di bagian utara terdapat alur jalur aliran permukaan yang masuk ke telaga, sehingga menyebabkan pengendapan intensif dari material aliran permukaan yang mengendap masuk ke telaga.

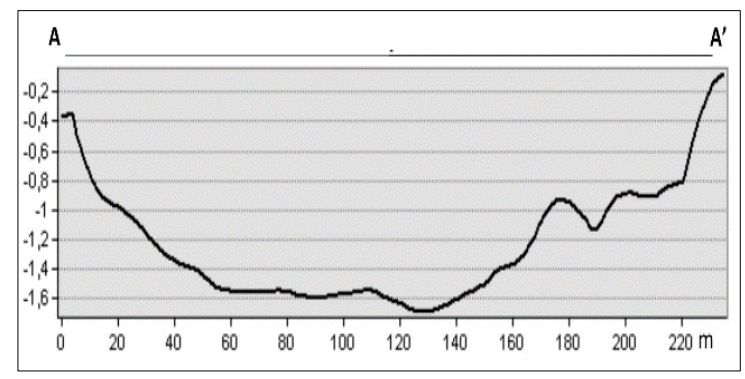

Gambar 9. Penampang A-A' 


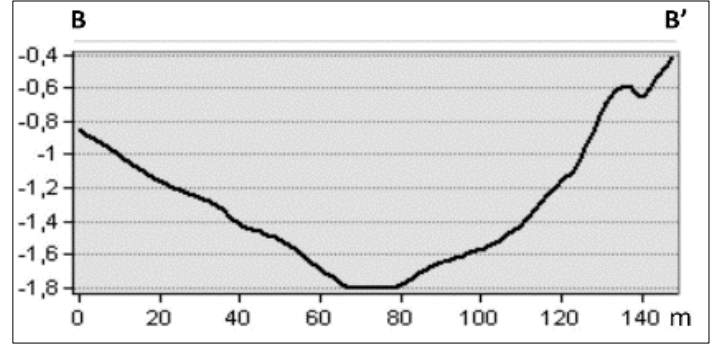

Gambar 10. Penampang B-B'

\section{Simpulan}

Metode interpolasi data kedalam dasar telaga dengan nilai error / RMSE terkecil yaitu kriging dengan nilai 0,005. Interpolasi kriging merupakan menunjukkan nilai simpangan nilai mean yang terkecil, sehingga data tersebut representatif dari populasi data kedalaman. Hasil interpolasi menunjukkan hasil yang paling halus, dikarenakan terjadi perataan data disekitar sampel yang diinterpolasi. Kedalaman Telaga Winong berkisar 0,2 - 1,8 m dengan lokasi terdalam berada di tengah dari telaga dan semakin dangkal di sekeliling batas telaga. Bagian telaga di utara mengalami pendangkalan dikarenakan pengendapan dari material aliran permukaan (erorsi permukaan) yang masuk ke ke dalam telaga.

\section{Ucapan Terima Kasih}

Ucapan terima kasih disampaikan kepada Pemerintah Desa Kepek Kecamatan Saptosari dalam memfasilitasi kegiatan ini dan Lilik Ismangil dari Laboratorium Hidrologi dan Kualitas Air yang membantu penelitian ini.

\section{Referensi}

Asdak C., (2010). Hidrologi dan Pengelolaan Daerah Aliran Air Sungai: Edisi. Revisi Kelima. Yogyakarta: Gadjah Mada University Press Yogyakarta.

Badan Standardisasi Nasional, (2016). Standar Nasional Indonesia (SNI) Nomor 8283:2016. Metode Pengukuran Kedalaman Menggunakan Alat Perum Gema Untuk Menghasilkan Peta Batimetri. BSN: Jakarta.
Badan Standarisasi Nasional, (2014). Standar Nasional Indonesia (SNI) Nomor 7645-1:2014 Klasifikasi Penutup Lahan- Bagian 1: Skala Kecil dan Menengah. BSN: Jakarta.

Bappeda Kabupaten Gunungkidul, (2007).

Penyusunan Neraca Air Kabupaten Gunungkidul, Daerah Istimewa Yogyakarta. Laporan Penelitian. Wonosari: Bappeda Kabupaten Gunungkidul.

Febriarta E., (2016). Sedimentasi Telaga Winong Sapotosari, Gunungkidul, Yogyakarta. Laporan Akhir. Institut Teknologi Yogyakarta: Yogyakarta.

Garmin, (2015). Manual Garmin GPS Maps And Echosounder Garmin. Garmin: AmericaColorado.

Isaaks, E.H. dan Srivastava, R.M. (1989). An introduction to applied geostatistics. New York: Oxford University Press

McComas, S. (2003). Lake and Pond Management Guidebook. London: Lewis Publisher.

Merwade V., Joff G., Maidment, D.R. (2006). Anisotropic considerations while interpolating river channel bathymetry. Journal of Hydrology 331 (3): 731-741

Mitas L., \& Mitasova H., (1999). Spatial Interpolation. Geographycal Information System Principles, Mnagement and Application. Wiley: New York.

Pusat Pendidikan dan Pelatihan Sumber Daya Air dan Konstruksi Dinas Pekerjaan Umum (PPPSDAK.PU), (2017)a. Konsep Kebijakan Perencanaan Embung. Pusat Pendidikan dan Pelatihan Sumber Daya Air dan Konstruksi Dinas Pekerjaan Umum: Jakarta.

Pusat Pendidikan dan Pelatihan Sumber Daya Air dan Konstruksi Dinas Pekerjaan Umum (PPPSDAK.PU), (2017)b. Perencanaan Embung.Pusat Pendidikan dan Pelatihan Sumber Daya Air dan Konstruksi Dinas Pekerjaan Umum: Jakarta.

Singhal, B.B.S., \& Gupta, R.P., (2010). Applied Hydogeology of Fracture Rock. Springer Dordrecht Heidelberg London: Springer. 
Surono B., Toha dan Sudarno I., (1992). Peta

Geologi Lembar Surakarta-Girintontro, Jawa.

Pusat Penelitian Dan Pengembangan

Geologi: Bandung.

Talif M., (2017). Analisa Data Multibeam

Echosunder Dan Side Scan Sonar Untuk

Identifikasi Fitur Dasar Laut Di Perairan

Kepulauan Riau (Tugas Akhir). Jurusan Teknik

Geomatika Fakultas Teknik Sipil Dan

Perencanaan. Institut Teknologi Sepuluh

November: Surabaya.

Widyastuti M., \& Haryono E., (2016) Water Quality

Characteristics of Jonge Telaga (Doline Pond)

as water Resources for the People of Semanu

District Gunungkidul Regency. Indonesia

Journal Of Geography.48(2).157-

167.doi.org/10.22146/ijg.17595.

White, W.B, (1988).Geomorphology and Hydrology of Karst Terrains. New York: Oxford University Press.

Wackernagel H., (2003). Multivariate Geostatistics. Springer: Switzerland.

Yozantika M., Heliani S.L., (2015). Pengaruh Kecepatan Gelombang Akustik Pada Data Batimetri Hasil Postprocessing MultiBeam Echosounder Menggunakan Software MBSystem (Skripsi S1). Teknik Geodesi Universitas Gadjah Mada: Yogyakarta. 